\title{
Beneficial Ownership in Tax Treaties: Judicial Interpretation and the Case for Clarity
}

Jinyan Li

Osgoode Hall Law School of York University, jli@osgoode.yorku.ca

\section{Recommended Citation}

$\mathrm{Li}$, Jinyan, "Beneficial Ownership in Tax Treaties: Judicial Interpretation and the Case for Clarity" (2012). Comparative Research in Law \& Political Economy. Research Paper No. 4/2012.

https://digitalcommons.osgoode.yorku.ca/clpe/4

This Article is brought to you for free and open access by the Research Papers, Working Papers, Conference Papers at Osgoode Digital Commons. It has been accepted for inclusion in Comparative Research in Law \& Political Economy by an authorized administrator of Osgoode Digital Commons. 


\section{OSGOODE}

OSGOODE HALL LAW SCHOOL

YOR K UN I VERS I T Y

\section{OSGOODE HALL LAW SCHOOL}

Comparative Research in Law \& Political Economy

RESEARCH PAPER SERIES

Research Paper No. 4/2012

\section{Beneficial Ownership in Tax Treaties: Judicial Interpretation and the Case for Clarity}

Jinyan Li

Editors:

Peer Zumbansen (Osgoode Hall Law School, Toronto, Director Comparative Research in Law and Political Economy)

John W. Cioffi (University of California at Riverside)

Leeanne Footman (Osgoode Hall Law School, Toronto, Production Editor)

Comparative Research in Law \& Political Economy 


\title{
Beneficial Ownership in Tax Treaties: Judicial Interpretation and the Case for Clarity
}

\author{
Jinyan $\mathrm{Li}^{1}$
}

\section{Introduction}

Beneficial owner is one of the most important concepts used in tax treaties. It limits the benefit of treaty-reduced withholding taxes on dividends, interest and royalties to recipients who are beneficial owners of such income. The term has been adopted in most bilateral tax treaties, but defined in none. Its meaning is thus left to be interpreted under Art. 3(2) of the OECD Model Tax Convention on Income and on Capital (the Model). Because the term has no specific meaning in the domestic tax law of most countries, the way in which domestic courts should interpret this treaty-originated concept has been the subject of much scholarly debate. ${ }^{2}$

There had been very little case law on the interpretation of the term beneficial owner until the UK Court of Appeal's decision in Indofood. ${ }^{3}$ This

1. Professor, Osgoode Hall Law School of York University, Canada. The author thanks Leo Xu and Simon Leith for their excellent research assistance, Rick Krever and Scott Wilkie for their comments on the earlier draft of this paper.

2. Avi-Yonah, R. and C. HJI Panayi, "Rethinking Treaty-Shopping Lessons for the European Union" (January 2010), available at www.law.umich.edu/centresand programs/elsc/abstracts/pages/papers.aspx; Baker, P., "The United Nations Model Double Taxation Convention Between Developed and Developing Countries: Possible Extension of the Beneficial Ownership Concept" - Annex to "Progress Report of Subcommittee on Improper Use of Tax Treaties: Beneficial Ownership", e/c.18/2-8/CRP.2/Add.1, 17 October 2008; De Broe, L. International Tax Planning and Prevention of Abuse: A Study under Domestic Tax Law, Tax Treaties and EC Law In Relation to Conduit and Base Companies (Amsterdam: IBFD, 2007); Elliffe, C., "The Interpretation and meaning of 'beneficial owner' in New Zealand" [2009] BTR, p. 276; Ward, D. A., "Access to Tax Treaty Benefits", Research Report Prepared for the Advisory Panel on Canada's System of International Taxation September 2008, available at www.apcsit-gcrcfi.ca; Fraser, R. and Oliver, J.D.B. "Beneficial Owner: HMRC's Draft Guidance on Interpretation of the Indofood Decision", [2007] BTR, pp. 39-57; Oliver, J.D.B., Libin, J.B., Van Weeghel, S. and Toit, C. "Beneficial Ownership and the OECD Model", [2007] BTR, p. 27 at 37; Vogel, K., Klaus Vogel on Double Taxation Conventions (3rd ed), (The Hague: Kluwer Law International, 1977) at 561; Du Toit, C.P., Beneficial Ownership of Royalties in Bilateral Tax Treaties, (Amsterdam: IBFD, 1999); Van Weeghel, S., The Improper Use of Tax Treaties (The Hague: Kluwer Law International, 1998).

3. Indofood International Finance Ltd v. JP Morgan Chase Bank NA [2006] EWCA Civ. 158, STL 1195. 
case has been accompanied by several others, including Bank of Scotland, ${ }^{4}$ Real Madrid ${ }^{5}$ and Prévost. ${ }^{6}$ These cases have attracted a great deal of attention in the international tax community. Upon reflection, though, one wonders if they have actually advanced our understanding about such basic questions as:

- To what extent is domestic law meaning relevant to the interpretation of a unique treaty concept??

- Should there be an autonomous international meaning given to this term?

- Is factual or economic substance consideration relevant in the determination of whether the formal owner is the beneficial owner of income? If so, how?

- How relevant are later OECD Commentaries?

This paper demonstrates how courts have attempted to answer these questions, and makes some general observations about where the courts have diverged and converged on this matter. The main conclusion of this paper is that by leaving the interpretation to domestic courts, "there seems little chance of there being an accepted universal meaning" of the term beneficial ownership. ${ }^{8}$ Lastly, the paper makes the case for clarity through the revision of the Commentary.

\section{Difficulties in interpreting beneficial owner}

Pursuant to Art. 3(2) of the Model, undefined treaty terms are to be given the meaning that they have under the relevant domestic law unless the context of the treaty otherwise requires. This rule presumes that the undefined term has a meaning under domestic law and that the context can be established. In the case of beneficial ownership, however, neither presumption is

4. Conseil d'Etat, 29 December 2006, Ministre de L'Economi, des Finances et de L'Industrie v. Societe Bank of Scotland, no.283314. See 91 TLR 1.

5. Real Madrid F.C. v. Oficina Nacional de Inspeccion (18 July 2006), Westlaw Aranzadi JUR 20061204307. For commentary, see Adolfo Martin Jimenez, IBFD-Tax Treaty Case Law Database: http://online2.ibfd.org/highligh/collections/ttcls.html.c1_ es_2006-07-18_1-summary.html

6. Prévost Car Inc. v. Canada, 20083080 (TCC), aff'd by FCA, 2009 DTC 5053.

7. De Broe, note 2, at 668. See also Vogel, note 2, at 562; Baker, note 2, Para. 29.

8. Avery Jones, J. et al., "The Treatment of Trusts under the OECD Model Convention” 29 European Taxation (1989), p. 379. 
realistic. Domestic judges must thus rely on the legal principles and traditions known to them, which may vary from one jurisdiction to another.

\subsection{Unique treaty concept}

Beneficial owner is a unique treaty concept in the sense that it is used almost exclusively in treaties based on the OECD Model, and has no clear meaning under the domestic tax law of most countries. It originated in the United Kingdom and was used to distinguish from legal ownership in circumstances where the legal ownership was akin to a nominee or agent. ${ }^{9}$ Since its adoption into the Model in 1977, beneficial owner has been incorporated into the UN Model Convention and the vast majority of bilateral tax treaties. ${ }^{10}$

The meaning of beneficial owner is elusive under the domestic law of most countries. Civil law countries do not use this concept, creating an issue of compatibility of the transplanted treaty concept with domestic law. ${ }^{11}$ Even in common law countries, the meaning is not clearly established. For example, the Canadian Income Tax $\mathrm{Act}^{12}$ uses this term without defining it.

\subsection{Divergent legal traditions}

Courts in different legal traditions adopt different approaches to the interpretation of tax statutes and tax treaties. For example, in civil law traditions, the doctrine of abuse of rights is used to combat tax avoidance, including treaty shopping. ${ }^{13}$ Courts tend to interpret tax legislation purposively and characterize facts in accordance with the substance of the transactions, and are more willing to recognize the doctrine of treaty abuse. ${ }^{14}$

9. Van Weeghel, note 2, at 65. Baker, note 2.

10. In Prévost, the Tax Court of Canada noted in Para. 60 that this term was used in 85 of Canada's 86 tax treaties. Only Canada's treaty with Australia uses the term "beneficially entitled".

11. De Broe, note 2, at 668 .

12. RSC 1985 (5th supp.), c.1. For further discussion, see Brender, M., "Beneficial Ownership in Canadian Income Tax Law," Symposium: Beneficial Ownership and the Income Tax Act" 51 Canadian Tax Journal (2003) No. 1, at 424-427.

13. This doctrine may be expressed as a statutory rule or an inherent principle of interpretation. See Prebble, Z. and Prebble, J. "Comparing the General Anti-Avoidance Rule of Income Tax Law with the Civil Law Doctrine of Abuse of Law" 62 Bulletin for International Taxation (2008) p. 151; Ward, note 2, at 29-36; Ward, D.A. et al., "The Business Purpose Test and Abuse of Rights" [1985] BTR, p. 68.

14. See Bank of Scotland, note 4. Indofood may be considered an example as well since the UK Court referred to the domestic anti-abuse doctrine adopted by Indonesian court. 
In contrast, courts in common law jurisdictions (other than the United States) have not embraced the anti-abuse doctrine. ${ }^{15}$ The legislatures in Canada, Australia and New Zealand enacted a general anti-avoidance rule (GAAR) to instruct the courts to interpret taxing statutes in accordance with the object and purpose of the legislation. ${ }^{16}$ Even after the introduction of the GAAR, Canadian courts have consistently rejected the substance-over-form doctrine. ${ }^{17}$

\subsection{Controversy over treaty shopping}

Under Art. 3(2), the domestic law meaning of an undefined treaty term applies if the context of the treaty does not otherwise require. Context is determined in particular by the intention of the contracting, and the meaning in the legislation of the other contracting state (an implicit reference to the principle of reciprocity on which the Model is based).${ }^{18}$ OECD Commentaries are generally considered as part of the context.

The notion of treaty shopping is believed to have originated in the United States to aptly describe a phenomenon where "a person 'shops' into an otherwise unavailable treaty through complicated structures". ${ }^{19}$ Treaty shopping is a form of tax avoidance as opposed to tax evasion. It is controversial whether treaties are intended to prevent tax avoidance.

Other examples include A Holdings ApS v. Federal Tax Administration, 8 ITLR (2005) 536, in which the Swiss Federal Court said (in translation) that there is an anti-abuse doctrine in treaty law which prohibits the use of an institute of law against its purpose to realize interests which are not protected by it.

15. For a discussion of the GAAR in common law countries, see Arnold, B.J., "A comparison of statutory general anti-avoidance rules and judicial general anti-avoidance doctrines as a means of controlling tax avoidance: Which is better? (What would John Tiley think?)" in Comparative Perspectives on Revenue Law: Essays in Honour of John Tiley, edited by Avery Jones, J., Harris, P. and Oliver, J.D.B. (Cambridge: Cambridge University Press, 2008).

16. In Canada, for example, the GAAR was enacted in 1988 to overrule the Supreme Court of Canada's decision in Stubart, which rejected the business purpose doctrine, and held that taxpayers' rights to minimize taxation had been well entrenched in Canadian law. See Li, J., "Economic Substance": "Drawing the Line Between Legitimate Tax Minimization and Abusive Tax Avoidance", [2006] Vol. 54, no.1 Canadian Tax Journal p. 23.

17 The Supreme Court of Canada stated in Shell Canada Limited v. The Queen, 99 DTC 5669, at Para. 39: "[T]his Court has never held that the economic realities of a situation can be used to recharacterize a taxpayer's bona fide relationships. To the contrary, we have held that, absent a specific provision of the Act to the contrary or a finding that they are a sham, the taxpayer's legal relationships must be respected in tax cases. Recharacterization is only permissible if the label attached by the taxpayer to a particular transaction does not properly reflect the actual legal effect."

18. OECD Commentary on Art. 3, Para. 12.

19. Avi-Yonah and Panayi, note 2, at 2-4. 
In terms of tax policy, treaty shopping may be regarded as abusive tax avoidance or the improper use of tax treaties, an instrument for advancing the intended purpose of a tax treaty, or a form of acceptable tax planning. The OECD considers treaty shopping problematic for three primary reasons: it breaches the principle of reciprocity; ${ }^{20}$ it results in double non-taxation or inadequate taxation; ${ }^{21}$ and it destroys the incentive for countries to negotiate and conclude new treaties. ${ }^{22}$ The UN Treaty Shopping Report ${ }^{23}$ suggests that there may be public benefits in allowing treaty shopping. Some countries that are keen on attracting investment may actively desire that dividends or interest paid to a recipient in a treaty country be subject to low or no withholding tax, even if the recipient is a holding company for shareholders based in third countries. Double non-taxation caused by treaty shopping is thus not a basis for objection in all cases. The report also notes that, if one of the general objectives of tax treaties is to promote "freer flows of international trade and investment, it may be generally arguable that it does not matter if the desirable result is achieved by the direct use of tax treaties or by their indirect use [i.e. treaty shopping]". ${ }^{24}$ Some developing countries may regard treaty shopping as a form of tax incentive to attract scarce foreign capital. For example, the Indian Supreme Court considered that treaty shopping was a necessary evil in a developing economy and is generally valid under the Indian tax treaty network. ${ }^{25}$

Courts in different countries have adopted different levels of tolerance to treaty shopping. The French courts considered the treaty shopping arrangement in Bank of Scotland abusive, while Canadian courts stated that there is nothing inherently proper or improper with selecting one foreign regime over another and that (treaty) shopping - on its own cannot be viewed as being abusive. ${ }^{26}$

20. OECD, Double Taxation Conventions and the Use of Conduit Companies, adopted by the OECD Council on 27 November 1986 (the OECD Conduit Report), at 90.

21. OECD Commentary, Art. 1 Paras. 8, 9 and 11.

22. OECD Conduit Report, note 20, at 90.

23. UN, Department of International Economic and Social Affairs, Contributions to International Co-operation in Tax Matters: Treaty Shopping, Thin Capitalization, Cooperation between Tax Authorities, Resolving International Tax Disputes (UN: New York, 1988), at 7.

24. Id.

25. Union of India v. Azadi Bachao Andolan, [2003] 6 ITLR 233. For a review of this case, see Baistrocchi, E., "The Use and Interpretation of Tax Treaties in the Emerging World: Theory and Implications", [2008] BTR, p. 352. China, on the other hand, holds a different view - treaty shopping is generally abusive. For further comments, see Yang, H., "New Developments in the General Anti-Abuse Rules and the Impact on International Tax Planning" Asia-Pacific Tax Bulletin (May/June 2009) p. 176.

26. MIL (Investments) SA v. The Queen, 2006 DTC 3307 (TCC), Para. 69. 


\subsection{Ill-defined bargain between treaty partners}

The concept of beneficial ownership is a tool to protect the bargain between the two contracting states. The fundamental underpinnings of a treaty are mutual concessions by treaty partners, each in its own interest. Neither country would intend to relinquish its tax base without getting something back for it. Beneficial owner is used to confine the bargain to the parties who were intended to benefit from it. If the benefits of the treaty are deliberately channelled to outsiders, it defeats the bargain. On the other hand, one treaty partner might say that it intends to set itself up as a conduit regime, and if the other partner doesn't like it, it should do something about it. The difficulty is that this question requires a point of reference that, arguably, does not exist in a legal sense. Hence, interpretation of the meaning of beneficial ownership becomes difficult.

\section{Judicial interpretation}

\subsection{The leading cases}

The four cases on beneficial ownership deal with the question of whether an interposed company located in a treaty-friendly jurisdiction (Netherlands in Indofood and Prévost, Hungary in Real Madrid, and United Kingdom in Bank of Scotland) is a beneficial owner for the purpose of the respective treaty. The income that is "channelled" through the interposed company is interest in Indofood, royalties in Real Madrid, dividends in Prévost, and dividends (recharacterized as interest) in Bank of Scotland. The judgments in Indofood and Prévost were written in a typical common law style-detailed, and relatively well reasoned. The Bank of Scotland and Real Madrid decisions are much shorter, written by judges who "are trained to keep their thoughts to themselves" ${ }^{27}$ The courts have adopted different approaches to the interpretation of beneficial ownership.

\subsubsection{Indofood}

Indofood is a leading case on beneficial ownership. For the first time, a UK court had to provide a definition of the term beneficial owner in a treaty.

27. Ward, note 2, at 173 . 
The facts of the Indofood case are complex. An Indonesian company, Indofood, set up a Mauritian special purpose vehicle (Issuer) to issue loan notes. Back-to-back loan arrangements were put in place. The loan notes contained a gross-up clause and provided for early redemption in case that, due to tax or treaty changes, the Issuer had to pay additional tax in Indonesia. The notes also contained a clause requiring the Issuer to try to mitigate any additional tax liability by taking reasonable measures available to it before seeking to redeem the notes. The financing was structured via Mauritius in order to take advantage of the lower withholding tax rates under the Indonesia-Mauritius treaty. Mauritius has no outbound withholding taxes. In reaction to the problem of abuse of the treaty by conduit companies, Indonesia terminated its treaty with Mauritius effective 1 January 2005, thus increasing Indonesian withholding tax on the interest payments from a $10 \%$ treaty rate to $20 \%$ standard rate. Since the issue of the notes in 2002, both interest and exchange rates had moved against Indofood and in favour of the noteholders. Indofood sought to redeem the notes and refinance them at a cheaper rate. JP Morgan Chase, acting as trustee for the bondholders, was not satisfied that the best endeavours clause had been complied with. It alleged that Indofood could have interposed a Dutch Newco into their structure and availed of the preferable rates under the Netherlands-Indonesia treaty. Therefore, JP Morgan refused to approve the redemption. The main substantive issue at trial was whether Newco would be the beneficial owner of the interest payable to it by Indofood for the purposes of the Indonesia-Netherlands treaty. The case was heard in the United Kingdom because the choice of law was English law.

The UK High Court ${ }^{28}$ found that Newco would be the beneficial owner of the interest, noting:

It is clear that Newco, $[\ldots]$ will not be a nominee or agent for any other party and, not being any sort of trustee or fiduciary, will have power to dispose of the interest when received as it wishes, although it will be constrained by its contractual obligation to the Issuer to apply the proceeds of the interest payments in performance of those obligations. ${ }^{29}$

The Court of Appeal overturned the High Court's decision and held that Newco could not be the beneficial owner of the interest received from Indonesia for purposes of the Indonesia-Netherlands treaty. The Court adopted an international fiscal meaning by relying on the OECD Commentary and the published views of Philip Baker. For example, the Court quoted with approval the following from the Commentary:

28. Indofood, note 3.

29. Id., Para. 46. 


\begin{abstract}
Where an item of income is received by a resident of a Contracting State acting in the capacity of agent or nominee it would be inconsistent with the object and purpose of the Convention for the State of source to grant relief or exemption merely on account of the status of the immediate recipient of the income as a resident of the other Contracting State. The immediate recipient of the income in this situation qualifies as a resident but no potential double taxation arises as a consequence of that status since the recipient is not treated as the owner of the income for tax purposes in the State of residence. It would be equally inconsistent with the object and purpose of the Convention for the State of source to grant relief or exemption where a resident of a Contracting State, ... simply acts as a conduit for another person who in fact receives the benefit of the income concerned. For these reasons, the [Conduit Companies Report] concludes that a conduit company cannot normally be regarded as the beneficial owner if, though the formal owner, it has, as a practical matter, very narrow powers which render it, in relation to the income concerned, a mere fiduciary or administrator acting on account of the interested parties. ${ }^{30}$
\end{abstract}

The Court concluded that "the concept of beneficial ownership is incompatible with that of the formal owner who does not have the full privilege to directly benefit from the income". ${ }^{31}$ The phrase "full privilege to directly benefit from income" is not from the Commentary or Philip Baker's writings, but a circular letter issued by the Indonesian tax authorities.

\title{
3.1.2. Bank of Scotland
}

The French Supreme Administrative Court (Conseil d'Etat) denied benefits under the France-UK treaty to Bank of Scotland, a resident of the United Kingdom, on the receipt of dividends paid by a French company. Bank of Scotland had acquired from a US corporation a usufruct for three years over non-voting shares that were specifically issued in respect of this arrangement. The bank paid FRS 270 million for the usufruct but they were in turn entitled to dividends which amounted to an amount slightly more than FRS 270 million. The US corporation agreed to indemnify the bank if the French subsidiary was unable to pay the dividends and or where the French Treasury would not pay the dividend tax credit. The US corporation agreed to give all financial support to the French subsidiary to enable it to pay the dividends and the bank could step out of the transaction where the subsidiary did not meet certain profit thresholds.

30. Id., Para. 32. The Court noted that Philip Baker suggests that the term should be accorded an international fiscal meaning not derived from the domestic laws of contracting states.

31. Indofood, note 3, Para. 46. 
This arrangement was designed to benefit from the dividend tax credit under Art. 9(7) of the France-UK treaty that has no counterpart in the France-US treaty. If the bank were successful in receiving the repayment of the dividend tax credit, it would receive Frs 74.25 million more than its initial investment of Frs 270 million.

The Conseil d'Etat reversed the decision of the lower court, which found that the Bank was not an artificial conduit interposed between the US corporation and the French subsidiary, nor that it acted as a nominee or an agent of the US corporation in collecting the dividends. The Conseil d'Etat recharacterized the transaction between the bank and the US corporation as a disguised loan and held that the US corporation continued to be the beneficial owner of the dividends.

\subsubsection{Real Madrid}

The taxpayer was a Spanish football club. It made payments to a Hungarian company for the right to use image rights for one of its players. The Hungarian company immediately transferred $99 \%$ of the amounts received to a Netherlands company. The Spanish tax authorities denied the zero withholding tax on royalties provided by the Hungary-Spain treaty on the ground that the Hungarian company was interposed for the sole purpose of benefiting from this treaty, and thus, not a beneficial owner.

The Court upheld the tax authorities' decision. In the court's view, this is a case where the context otherwise requires. Therefore, reference to domestic law is excluded and the autonomous international meaning should be applied. The Court relied on OECD materials in concluding that "the clear objective of the concept of beneficial owner is its function as a device against any form of treaty shopping" and "an economic interpretation can be applied to find the 'real owner' of the income whereby the legal ownership of income could be disregarded". ${ }^{2}$

\subsubsection{Prévost}

Prévost is the first Canadian case on the interpretation of beneficial owner in tax treaties. The facts of the case are straightforward. Prévost is a company located in the province of Quebec (a civil law jurisdiction) and is a resident

32. Real Madrid, note 5, Para. 2. 
of Canada. In 1995, Volvo, a company resident in Sweden, acquired all the shares of Prévost, and shortly after the acquisition transferred the shares to a Dutch holding company (Holdco). Later, Henlys, a UK company, acquired $49 \%$ of the shares of Holdco. Pursuant to a shareholders' agreement, Volvo and Henlys agreed that Prévost and the Holdco distribute at least $80 \%$ of their profits to the shareholders. Prévost paid dividends to Holdco according to the predetermined dividend policy and withheld and remitted tax at the rate of 5\% under the Canada-Netherlands treaty. Holdco then distributed the dividends received from Prévost to Volvo and Henlys. The Canada Revenue Agency assessed the Canadian withholding tax on the basis that Holdco was not the beneficial owner of the dividends.

Rip, J. of the Tax Court of Canada held that Holdco was the beneficial owner of the dividends. ${ }^{33} \mathrm{He}$ rejected the Crown's position that beneficial ownership should have an internationally recognized interpretation instead of a domestic solution. Rip, J. stated:

I am being asked to determine what the words 'beneficial owner' and 'bénéficiaire effectif' (and the Dutch equivalent) mean in Article 10(2) of the Tax Treaty. Article 3(2) of the Tax Treaty requires me to look to a domestic solution in interpreting 'beneficial owner'. The OECD Commentaries on the 1977 Model Convention with respect to Article 10(2) are also relevant. ${ }^{34}$

Because beneficial owner is undefined in the Canadian Income Tax Act, Rip, J. held that the ordinary meaning in private law governs. After considering the meaning of this term under Canadian common law, income tax law, the Civil Code of Quebec, ${ }^{35}$ and Dutch law, ${ }^{36}$ he concluded that "in both common law and the civil law, the persons who ultimately receive the income are the owners of the income property." ${ }^{37}$

In my view the 'beneficial owner' of dividends is the person who receives the dividends for his or her own use and enjoyment and assumes the risk and control of the dividend he or she received. The person who is beneficial owner of the dividend is the person who enjoys and assumes all the attributes of ownership. ${ }^{38}$

33. The withholding tax rate for dividends is $10 \%$ under the Canada-UK treaty and $15 \%$ under the Canada-Sweden treaty, but $5 \%$ under the Canada-Netherlands treaty.

34. Prévost (TCC), note 6, Para. 95.

35. Id., Paras. 97 and 98.

36. The court relied on experts from the Netherlands on the meaning of Dutch law. These experts include Van Weeghel, Rogier Raas, and Daniel Lüthi.

37. Prévost (TCC), note 6, Para. 99.

38. Id., Para. 100. 
Rip, J. cited the OECD materials as part of general background information without relying on them in his analysis. He did indicate - in an apparent implicit reference to the Conduit Report and the 2003 Commentary - that a conduit company is not a beneficial owner, but conspicuously said nothing more about the notion of conduit company. ${ }^{39}$

Rip, J. concluded that Holdco was the beneficial owner of dividends on the basis of the legal relationships and Dutch corporate law. ${ }^{40}$ The relationship between Holdco and its shareholders is not one of agency, nor one where the property is in the name of a nominee. Holdco was the registered owner of Prévost shares, paid for the shares and owned the shares for itself. When dividends are received by Holdco, the dividends are the property of Holdco and are available to its creditors, if any, until such time as the management board declares a dividend.

Rip, J. found that Holdco was not a conduit because: (a) it is not a party to the shareholder agreement that required a distribution of a minimal $80 \%$ of after-tax profits; (b) it cannot be said to have "absolutely no discretion as to the use or application of funds put through it as a conduit"; and (c) it has not "agreed to act on someone else's behalf pursuant to that person's instructions without any right to do other than what that person instructs it, for example a stockbroker who is the registered owner of the shares it holds for clients". There was no predetermined or automatic flow of funds to them. As a corporate entity, Holdco carried on business operations in accordance with the Dutch law under which it was constituted. Its corporate veil cannot be pierced. Holdco's deed of incorporation did not obligate it to pay any dividend to its shareholders; when it decides to pay dividends, it must pay the dividends in accordance with the Dutch law.

There are some facts in this case that were not considered relevant by the court. In one instance, over $\$ 5$ million was transferred by Prévost to Henlys without properly signed resolution of the managing directors of Holdco. In documentation provided to its banker, Holdco had declared that the shares of Prévost were beneficially owned by Volvo and Henlys. One of Prévost's corporate minute book confused Volvo and Henlys with its actual sole shareholder, Holdco. The court noted that "this is at least sloppy maintenance of corporate records but could also be an indication of something more significant", but did not draw any inference from it.

39. Id., Para. 96.

40. Id., Paras. 100-105. 
The Federal Court of Appeal upheld Justice Rip's decision. It also found that Justice Rip's definition of beneficial owner accords with what is stated in the OECD Commentaries and in the Conduit Report. In fact, at least half of the Court's judgment deals with the potential role of later Commentaries in interpreting a pre-existing treaty. More notably, the Court remarked that "later commentaries can guide the treaty interpretation when they represent a fair interpretation of the words of the Model Convention and do not conflict with Commentaries in existence at the time a specific treaty was entered and when, of course, neither treaty partner has registered an objection to the new Commentaries". ${ }^{41}$

\subsection{Basic interpretive questions}

\subsubsection{Domestic law meaning or international meaning?}

The question of whether beneficial owner should have a domestic law meaning or international meaning has been controversial. Some commentators ${ }^{42}$ argue that the term should be given an autonomous international meaning rather than a domestic law meaning, on the grounds that: (a) it was introduced into international tax lexicon through the work of the OECD, then the UN Model; (b) while the term is widely incorporated into tax treaties, only some countries employ this term in their domestic law; and (c) the purpose of using this concept is to prevent treaty shopping, which is better achieved by common interpretation across countries. However, others argue that the domestic law meaning is relevant, especially in common law jurisdictions that employ the concept of beneficial owner in domestic law, as long as the domestic law meaning is consistent with the Commentaries. ${ }^{43}$

The courts in Indofood and Real Madrid adopted an international fiscal meaning. In Prévost, on the other hand, Justice Rip adopted a domestic solution. However, because the Federal Court of Appeal, in obiter, regarded Justice Rip's approach to be consistent with the OECD position, which favours an international fiscal meaning, it is not very clear whether Prévost steadfastly stands for a domestic solution.

41. Prévost (FCA), note 6, Paras. 10 and 11.

42. See, for example, Baker, note 2; De Broe, L., note 2, at 662-675; Du Toit, note 2, at 173-177; Fraser and Oliver, note 2; Vogel, note 2, at 561.

43. See, for example, Elliffe, note 2 . 


\subsubsection{How to find an international meaning?}

In Indofood, the Chancellor quoted the Commentary, statements from the Indonesian tax authorities, and Philip Baker's writings extensively, ${ }^{44}$ to the effect that beneficial owner meant the "full privilege to directly benefit from the income". The Court in Real Madrid also referred to the OECD materials and applied the domestic business purpose test in determining if the interposed company was the beneficial owner. ${ }^{45}$ As such, although OECD materials were referred to, the conclusion in these two cases seemed to rest on the domestic law approach: Indonesian law as interpreted by the tax authorities in Indofood, and the Spanish business purpose test in Real Madrid. The reason for this is likely because the Commentary provides only a useful "rule of thumb" ${ }^{46}$ on the meaning of beneficial owner by concentrating on agents, nominees and conduit companies acting as mere fiduciaries or administrators. The Commentary provides no guidance on the factors to be considered in determining, factually and legally, whether the powers of the conduit company are akin to those of fiduciaries or administrators.

\subsubsection{Legal or practical determination?}

There are two schools of thoughts on whether beneficial owner should be interpreted in a strict legal sense to mean only legal conduits, or more practically in a business or economic sense to include factual conduits. The latter is suggested in the Commentary and the latter tends to be applied in countries that do not recognize the substance-over-form doctrine.

Under a technical legal approach, the term beneficial owner is construed in accordance with the legal rights possessed by the conduit entity. It does not involve a factual inquiry as to whether, in fact, the conduit has the benefit of income. A recipient of income will not be considered a beneficial owner if the recipient is a nominee, an agent, or where the legal obligations of the recipient to the beneficial owner are such that the recipient is a mere

44. Indofood, note 3, Para. 37.

45. See note 5, Para. 2. The court stated: "If there is a business reason to place an entity between the payer and the final recipient of the income beyond the reduction of withholding taxes in Spain, the intermediary will be the beneficial owner; however, if the only objective of the interposition of the intermediary is to obtain a reduction of withholding tax, there is no business purpose, and consequently, the intermediary is not the beneficial owner of the income."

46. Baker, P. "Beneficial Ownership: After Indofood", GITC Review, Vol. VI No.1, available at www.taxbar.com/documents/Beneficial_Ownership_PB.pdf . 
fiduciary or administrator of the funds and has only very narrow powers over the income. It is therefore essential to determine whether the conduit owns the income for its own benefit, rather than for the benefit of a third party on the basis of private law (such as contracts, corporate law, etc.). ${ }^{47}$ Prévost and the decision of the High Court in Indofood are examples of this technical legal approach. Real Madrid and Bank of Scotland and the Court of Appeal decision in Indofood applied the practical, substance-over-form approach. $^{48}$

The two approaches are best illustrated by the Indofood case. The High Court held that the interposed company was the beneficial owner of income. It started its analysis by examining the loan agreements and found that:

The Notes constitute direct, general and unconditional payment obligations of the Issuer which will at all times rank pari passu and without any preference among themselves and at least pari passu with all other present and future obligations of the Issuer, save for such obligations as may be preferred by provisions of law that are both mandatory and of general application. ${ }^{49}$

On the basis of the agreements, the High Court concluded that the Issuer was the beneficial owner of interest income. It also concluded that the proposed Newco would have the power to dispose of the interest received as it wished, although it was constrained by its contractual obligation with the Issuer to apply the proceeds of the interest received in performance of those obligations. The Court stated: "In no sense will Newco be acting as nominee or administrator for the Issuer or the Noteholders. It will merely be contractually bound to indemnify the Issuer against its obligations to those Noteholders. The Noteholders will have no claim to be the beneficial owners of the interest." ${ }^{50}$ The conclusion that Newco would be the beneficial owner was also supported by the fact that Dutch law requires a substance and risk test, requiring Newco to make a spread on the interest.

The Court of Appeal overturned the High Court's decision, and held that "the meaning to be given to the phrase beneficial owner is plainly not to be limited by so technical and legal an approach. Regard is to be had to the substance of the matter" ${ }^{51}$ Reference to the substance of the matter presumably is drawn from Indonesian civil law. The Court of Appeal remarked:

47. See De Broe, note 2, at 686-689.

48. In Aiken Industries, Inc. v Commissioner, 56 TC 925 (1971).

49. High Court (Chancery Division), 7 October 2005, Indofood International Finance

Ltd. v. JP Morgan Chase Bank, NA, London Branch, 8 ITLR 2005, at 236.

50. Id.

51. Indofood, note 3, Para. 44. 
In practical terms it is impossible to conceive of any circumstances in which the Issuer or Newco could derive any 'direct benefit' from the interest payable by [Indofood] except by funding its liability to the Principal Paying Agent or Issuer respectively. Such an exception can hardly be described as the 'full privilege' needed to qualify as the beneficial owner, rather the position of the Issuer and Newco equates to that of an 'administrator of the income'. ${ }^{52}$

\subsubsection{Anti-avoidance or basic rule?}

It is currently unclear whether beneficial owner is a legal concept or an anti-avoidance rule. In the sense that beneficial owner determines who is entitled to treaty benefits it is a basic concept. There was evidence that this concept was used in the US-UK tax treaty in the early 1960s to ensure that beneficiaries of pension funds did not lose source state treaty benefits simply because the pension fund that was the direct owner of the assets was not taxable. ${ }^{53}$ The OECD's recent report on collective investment vehicles, directed to the legal and practical issues associated with allowing source state treaty benefits for the benefit of investors in mutual funds and the like. ${ }^{54}$ On the other hand, there is evidence that this concept and the context in which it was introduced into the Model indicate an anti-treaty shopping purpose. $^{55}$

The cases are inconsistent on this issue. Prévost clearly regards beneficial owner as a legal concept. In this case, although the Canadian courts acknowledged the relevance of the Commentaries, they paid little attention to the anti-avoidance purpose mentioned in the OECD Commentaries. The Federal Court of Appeal clearly rejected any "pejorative view of holding companies". ${ }^{56}$ The courts in Bank of Scotland and Real Madrid seem to regard the beneficial ownership provision as a general anti-treaty shopping rule. In Bank of Scotland, for example, the Court applied the anti-abuse doctrine and found that the arrangement was entered into for the sole purpose of obtaining treaty benefit. Indofood is somewhat ambiguous since

52. Id., Para. 42.

53. See Oliver, J.D.B., et al., "Beneficial Owner in the OECD Model", [2001] BTR, p. 27.

54. The OECD Committee on Fiscal Affairs released a Report on "The Granting of Treaty Benefits with respect to the Income of Collective Investment Vehicles" on 23 April 2010. It contains proposed changes to the Commentary on the OECD Model dealing with the question of the extent to which either collective investment vehicles (CIVs) or their investors are entitled to treaty benefits on income received by the CIVs. 55. Arnold, B.J. "Tax Treaty News", Bulletin for International Taxation (2009) 175, at 176; Baker, note 2; and De Broe, note 2, at 654.

56. Prévost (FCA), note 6, Para. 15. 
the Court of Appeal did not explicitly state that the beneficial owner concept functions as a general anti-treaty shopping rule. Implicitly, however, it endorsed the position of the Indonesian tax authorities that treaty shopping constitutes an abuse or improper use of tax treaties.

\subsubsection{Relevance of later Commentary?}

There is a high-level of consensus that existing OECD Commentaries are relevant in treaty interpretation even though there is a lack of agreement on the legal basis ${ }^{57}$ or the proper weight of the Commentaries in the interpretation of tax treaties. ${ }^{58}$ The fact that very few treaty interpretation cases end up in court likely means that the Commentaries help prevent disputes as both taxpayers and the tax administration refer to the Commentaries for guidance. ${ }^{59}$

57. Sasseville, J. "Court Decisions and the Commentary", in Maisto, G. ed. Courts and Tax Treaty Law (Amsterdam: IBFD, 2007), pp. 189-200, summarizes the possible legal arguments in support of using the Commentary as a tool for the interpretation of tax treaties to include: (a) ordinary meaning under Art. 31.4 of the Vienna Convention; (b) special meaning under Art. 31.4 of the Vienna Convention; (c) part of the context of the treaty; (d) an instrument related to the treaty under Art. 31(2)(b) of the Vienna Convention; (e) supplementary means of interpretation under Art. 32 of Vienna Convention; (f) international consensus expressed in the OECD Recommendation; (g) OECD Recommendation would constitute a legal duty to interpret tax treaties according to the Commentary; and (h) doctrines of public international law, such as estoppel, acquiescence and reasonable expectations would justify not only looking at the Commentary but giving it a mandatory character.

58. There is extensive literature on the relevance of OECD Commentaries to treaty interpretation. See, for example, Ault, H.J., "The Role of the OECD Commentaries in the Interpretation of Tax Treaties," in Intertax, 1994, issue 4, p. 144; Lang, M., "Later Commentaries of the OECD Committee on Fiscal Affairs not to affect the interpretation of previously concluded tax treaties," 25 Intertax 1 (1997), p. 7; Sasseville, note 55; Vogel, K., "The Influence of the OECD Commentaries on Treaty Interpretation," 54 Bulletin for International Fiscal Documentation p. 12 (2000), p. 614; Ward, D., "References by domestic courts to decisions of foreign courts in interpreting tax treaties," in Maisto, note 57, pp. 161-187; Ward, D., et al., The Interpretation of Income Tax Treaties with Particular Reference to the Commentaries on the OECD Model (Amsterdam: IBFD Publications B.V., 2005). For an interesting exchange of views on the role of the Commentaries, see Ward, D., "The Role of the Commentaries on the OECD Model in the Tax Treaty Interpretation Process" 60 Bulletin for Fiscal Documentation 3 (2006) p. 97; Engelen, F., "Some Observations on the Legal Status of the Commentaries on the OECD Model," 60 Bulletin for Fiscal Documentation 3 (2006) p. 205; and Ellis, M., "The Role of the Commentaries on the OECD Model in the Tax Treaty Interpretation Process Responses to David Ward," 60 Bulletin for International Fiscal Documentation 3 (2006) p. 103.

59. The emergence of arbitration as a means to resolving tax disputes and the reliance on the mutual agreement procedure also increase the relevance of the Commentaries. The OECD-endorsed arbitration process requires that "issues of treaty interpretation 
The relevance of later Commentaries is less clear. At a technical level, it is difficult to see how later Commentaries constitute context, a basis for determining common intention of the negotiators for a special meaning or supplementary means of interpretation within the meaning of Arts. 31 or 32 of the Vienna Convention. At a practical level, however, if a taxpayer relies on the later Commentary in court, it is unlikely that the court of an OECD country would take the position that the taxpayer is not entitled to rely on an interpretation approved by the government of that country. ${ }^{60}$ In terms of the function of later Commentaries, a later Commentary may (a) fill a gap in the existing Commentary by covering matters not previously mentioned at all, (b) amplify the existing Commentary by adding new examples or arguments to what is already there, (c) record what states have been doing in practice, or (d) contradict the existing Commentary. Arguably, other than gap filling, later Commentaries deserve some weight in interpreting pre-existing treaties. ${ }^{61}$

Indofood, Prévost and Real Madrid confirmed the relevance of later Commentaries. The treaty under interpretation in these cases was concluded before the 2003 Commentary. The courts made no distinction between existing and later Commentaries in Indofood and Real Madrid. In Indofood, the Chancellor emphasized that his interpretation of beneficial owner "is entirely consistent with the various [OECD] Commentaries". ${ }^{62}$ In Prévost, the Federal Court of Appeal explicitly stated that the 2003 Commentary was relevant.

\subsection{Unsettling implications}

The international case law on beneficial ownership is inconsistent on the basic questions. This is very unfortunate as courts in different countries

will be decided by the arbitrators in light of the principles of interpretation incorporated in Arts. 31 to 34 of the Vienna Convention on the Law of Treaties, having regard to the Commentaries of the OECD Model Tax Convention as periodically amended [...]" See Sasseville, note 57, at 197, citing the OECD position available at the website: www.oecd.org/document/40/0,2340,en_2649_37427_38057000_1_1_1_37427,00.html. 60. Id. For more discussion, see Sasseville, note 57, at 193. Courts in France (Interhome $A G$ decision of 20 June 2003 (RJF 10/03 no. 1147), Canada (Federal Court of Appeal in Prévost Car) and other countries have recognized the persuasive value of later Commentaries. The Recommendation of the OECD Council (adopted by OECD Council on 23 October 1997) recommends the tax administrations of member countries to "follow the commentaries on the Articles of the Model Tax Convention, as modified from time to time, when applying and interpreting the provisions of their bilateral conventions that are based on these Articles."

61. See, Ward, et al., note 58, at 110.

62. Indofood, note 3, Para. 42. 
are increasingly turning to foreign cases for reference. For example, the Supreme Court of India, in dealing with the question that arose under the India-Mauritius treaty, referred to a host of foreign court decisions from Australia, Canada, the United States and the United Kingdom (all English language cases). ${ }^{63}$ Decisions in common law countries generally carry more weight because of the style of judicial writing and English language materials are more easily accessible. Even in civil law countries that do not recognize the principle of stare decisis, under which the ratio decidendi of a previous case in an appellant court or a higher court is recognized as having become part of the law and should be followed in that court and lower courts in all subsequent decisions,${ }^{64}$ courts frequently refer to foreign cases. For example, Austrian, French, German, and Dutch courts have referred to foreign tax cases in treaty cases. ${ }^{65}$

In terms of the impact on future court decisions, Prévost is arguably more influential than Indofood. Justice Rip is a highly respected tax expert in Canada. His decision was meticulously written, containing a detailed statement of facts, references to relevant Canadian, Dutch and OECD materials, a summary of the evidence given by four Dutch tax experts, and a careful analysis of the meaning of beneficial ownership under Canadian law. The decision was unanimously affirmed by a highly respected panel of appellate judges known for their tax expertise. ${ }^{66}$

63. See Ward, D.A., "Use of Foreign Court Decisions in Interpreting Tax Treaties" in Maisto ed., note 57, p. 161; Avery Jones, J. "Tax Treaties: The Perspective of Common Law Countries" in Maisto, ed., note 57, p. 31; Martin, Ph., "Courts and Tax Treaties in Civil Law Countries," in Maisto ed., note 57, 81. For example, in Prévost, the Tax Court of Canada referred to not only the court decision in the treaty partner state, but also to decisions of courts in third states, such as Indofood [Para. 70]. See also Azadi Bacho Andolan v. Union of India (2003) 6 ITLR 233.

64. Ward, note 63, at 167. Differences in the style of writing court judgments in civil law countries and common law countries are noted by Ward at 172-174 and Avery Jones, note 63, at 31-32. For further discussion, see Markesinis, B.S., "A Matter of Style", (1994) 110 LQR p. 607.

65. See "Country Surveys" in Maisto ed., note 57, including: Metzler, V., "Australia" p. 215; Perrot, T., "France”, p. 250; Rust, A., "Germany", pp. 268-269, and Marres, O., "Netherlands" p. 326.

66. Prévost (FCA), note 6, Para. 14. The Federal Court of Appeal wrote: The Judge's formulation captures the essence of the concepts of "beneficial owner", bénéficiaire effectif as it emerges from the review of the general, technical and legal meanings of the terms. Most importantly, perhaps, the formulation accords with what is stated in the OECD Commentaries and in the Conduit Companies Report. 
In contrast, Indofood confirms "one of the great fears of international tax lawyers" $" 67$ that a question concerning beneficial ownership would come before a court in a common law country with little or no expertise in international tax. This case was not strictly a tax case: the judges in Indofood were not tax experts, and the case was argued by counsel who had no tax expertise. "It is, in many respects, one of the most bizarre features of this case that a key issue concerning the meaning of a term used in multiple tax treaties was decided without any representation from a revenue authority and without the participation of anyone with any expertise in international tax before the Court of Appeal" ${ }^{68}$ Because Indonesia is a civil law jurisdiction that generally does not recognize the concept of beneficial ownership, the Court had to look elsewhere to find the meaning for this concept, and was thus more inclined to turn to international fiscal meaning. However, "it would be difficult to imagine that an UK court's view of what an Indonesian court might conclude in respect of the meaning of 'beneficial owner' for purposes of the Indonesia-Netherlands treaty is in any way relevant in determining the meaning of that term in any other international tax treaty." ${ }^{9}$

What is more unsettling is the fact that both Prévost and Indofood claim to be consistent with the OECD position. It is questionable whether the statement in Prévost was correct because the Commentary explicitly mentions that a conduit company cannot be the beneficial owner if it has, as a practical matter, very narrow powers ${ }^{70}$, and Justice Rip's interpretation of beneficial owner did not use a practical approach. ${ }^{71}$ At the same time, it is doubtful that the current Commentary supports the statement in Indofood that "a technical and legal approach to beneficial ownership should not be adopted, but regard should be had to the substance of the matter." 72

67. Baker, P., "Beneficial Ownership: After Indofood," first published in GITC Review Vol. VI No.1.

68. Id.

69. Chua, C. and Peters, M. "Indofood: a futile search for "beneficial owner" Asia Pacific Forum News (December 2008) 4, p. 7.

70. OECD Commentary on Art. 10, Para. 12.1.

71. It is possible that the Federal Court of Appeal, in saying what it did, simply wished to indicate that the outcome of the case would not have changed even if these OECD materials were used. See Kandev, M.N. and Wiener, B. "Prévost Car Inc. (FCA): Holdco Confirmed as Beneficial Owner of Dividends", CCH, Tax Topics, March 12, 2009, No.1931.

72. Commentators in common law countries have generally expressed concerns about the economic substance-over-form approach to the interpretation of "beneficial ownership". See, for example, Arnold, note 52, at 176 (the Indonesian court's endorsement of the "substance-over-form" doctrine in PT Transportasi Gas Indonesia was "most disturbing"); Baker, note 67, considered the statement in Indofood to be "less helpful" on the ground that "broad brush, substance approach was bound to lead to uncertainty". 
Overall, the general significance of these cases, especially Indofood and Prévost, is questionable. The circumstances of those cases very much affected how the courts approached them. As such, they may not be very useful for establishing overriding principles. For example, in Prévost, while the Court took a highly technical legal approach, the result was a practical accommodation to reality. This was evidenced by the fact that the Court decided to ignore sloppiness in the declaration and payment of dividends, seeing the case in effect, as a domestic shareholder loan case. Also, there was evidence in Prévost that the Canadian authorities were indifferent as to the result because it secured a treaty rate that was consistent with Canada's general treaty rate for direct dividends, a rate that at the time was intended that both the Swedish and UK treaties would have. Indofood was really just a commercial case, in which the tax principles were not well argued. There was also some doubt whether the original Indonesia-Maruitius planning structure actually worked. In effect, the Court in Indofood seemed to conclude that the mere interposition of a legal construction in a relationship and flow of interest income that existed and continued to exist as if the intermediary did not exist, would not be effective to change consequences. ${ }^{73}$

\section{Case for clarity through revising the OECD Commentary}

This section makes the case for more clarity through changes to the Commentary on the ground that international case law is confusing, causing uncertainty for taxpayers, and that revising the Commentary is the most practical solution.

\subsection{To clarify judicial interpretation}

There is precedence for the OECD introducing uniform approaches to treaty interpretation after an adverse court decision. Examples are the 2005 amendments to the Commentary on Art. 5 in reaction to the Italian Philip Morris case ${ }^{74}$ and the changes to the Commentary on Art. 3, and Art. 3 itself,

73. The author credits some of the ideas to comments made by Scott Wilkie on the draft of this paper.

74. Sasseville, note 57, at 197-198. Decisions of the Tax Chamber of the Supreme Court of Italy: Nos. 3367 and 3368 of 20 December 2001 (released on 7 March 2002), No.7682 of 20 December 2001 (released on 25 May 2002), No.10925 of 20 December 2001 (released on 25 July 2002). 
in reaction to the Supreme Court of Canada's decision in Melford.$^{75}$ There is a case for similar OECD reaction to clarify the meaning of beneficial owner.

\subsection{To provide more certainty}

Taxpayers face significant uncertainty with respect to the approach to interpreting beneficial owner. The degree of such uncertainty was evidenced by the panic reaction of the international tax community to the Indofood decision. In order to provide clarity, HMRC in the United Kingdom, while accepting Indofood as part of UK tax law, issued guidance to contain its impact, especially in the case of special purpose vehicles. ${ }^{76}$ The tax administration in other countries may not be prepared to limit Indofood in the same manner.

The potential impact of Prévost is uncertain. The Canada Revenue Agency is likely to litigate more treaty shopping cases. ${ }^{77}$ The Federal Court of Appeal's endorsement of later Commentary in Prévost may give the government new ammunition to try its argument in another case. In Prévost, the government argued, without success, that the interpretation of beneficial owner requires a search behind the legal relationships in order to identify the person who, as a matter of fact, can ultimately benefit from the income. The argument was made on the ground that the French word effectif means real or producing actual effects or resulting in real action, and the term bénéficiaire effectif means the person or group that actually and truly enjoys or benefits from an advantage of any kind. Justice Rip was not persuaded in Prévost, but another judge may be if the facts can be distinguished somewhat from this case. After all, the Federal Court of Appeal accepted the OECD position that favours an international fiscal meaning and a practical approach.

\subsection{To provide a practical solution}

The meaning of beneficial owner can be clarified through changes to the hard law or soft law. The former can be accomplished through the

75. The Queen v. Melford Developments Inc. (182), 139 DLR (3d) 577. For more discussion, see Sasseville, note 57, at 198.

76. UK HMRC, "HM Revenue \& Customs reaction to Indofood case", DT Claims and applications - Beneficial Ownership, INTM332050.

77. There is at least one case, Velcro v. Canada, 2007-1806 (IT)G. that is currently pending before the Tax Court. This case involves issues of beneficial ownership in a treaty context. 
introduction of either a definition of beneficial owner or a specific anticonduit company provision ${ }^{78}$ or general limitation-on-benefit clause. ${ }^{79}$

The bilateral nature of tax treaties means that changes to the hard law must be made to each treaty. Such treaty-by-treaty solution is highly unrealistic as it takes time to renegotiate tax treaties. Differences among treaties will continue to create opportunities for treaty shopping. The lack of a common meaning of beneficial owner inevitably means that uncertainty will continue. ${ }^{80}$

Alternatively, clarity may be provided through changes to soft law - the OECD Commentaries. The OECD has been recognized as a de facto international tax organization. The Model has been widely adopted by member states as well as non-member states.$^{81}$ National tax administrations and taxpayers look to the OECD for leadership in formulating policy dealing with emerging issues, such as e-commerce, international tax competition, and cross-border tax dispute resolution, most of which was accomplished through revision to the Commentary. In the absence of a multilateral tax treaty or international tax organization, the OECD is expected to continue to shape international tax policy.

The soft law approach is more practical because later Commentaries are likely considered by domestic courts in interpreting beneficial owner in future cases. Practically speaking, the OECD is in the best position to clarify if Indofood or Prévost is consistent with the Commentaries.

78. A specific rule may look like the following: "The provisions of this article shall not apply if it was the main purpose, or one of the main purposes, of any person concerned with the creation or assignment of the debt-claim in respect of which the interest is paid to take advantage of the Article by means of that creation or assignment." See Fraser, R. and J.D.B. Oliver, "Beneficial Ownership: HMRC's Draft Guidance on Interpretation of the Indofood decision", [2007] BTR p. 39 at 42.

79. A general limitation-on-benefit provision similar to a provision included in Art. 22 of the 2006 US Model has been included in some US treaties.

80. Avery Jones, J., "The David R. Tillinghast Lecture: "Are tax treaties necessary?" [1999] 53 Tax Law Rev.1, pp. 3-8.

81. See Cockfield, A.J. "The Rise of the OECD as Informal 'World Tax Organization' through National Responses to Ecommerce Tax Challenges," 9 Yale J. L. \& Tech. (2006) p. 59; Ring, D., "Who is Making International Tax Policy?: International Organizations as Power Players in a High Stakes World," 33 Fordham Int'l L.J. (forthcoming 2010). See also Tillinghast, D.R., "Commentaries to the OECD Model Convention: Ubiquitous, Often Controversial; But Could They Possibly Be Legally Binding?", 35 Tax Mgmt. Int'l 580 2006); and Avi-Yonah, R.S., "International Tax as International Law," 57 Tax L. Rev. (2004) p. 483. 
Ultimately, however, certainty is a relative notion. While the foundation of international tax law is shaky or incoherent,,$^{82}$ it is too much to ask for absolute certainty for the meaning of a concept that is supposedly intended to define the confines of the treaty bargain. The OECD Commentary can at least clarify the basic questions raised in this paper and provide some consistency for the interpretation of a unique treaty concept.

82. See, Kingson, C.I., "The Coherence of International Taxation", 81 Colum. L. Rev. 1151 (1981). 